\title{
Angiosperm disjunction “Campos rupestres - restingas": a re-evaluation
}

\author{
Ruy José Válka Alves ${ }^{1,3}$, Leonora Cardin² and Marcela Stuker Kropf ${ }^{2}$
}

Received: December 5, 2005. Accepted: January 17, 2007

\begin{abstract}
RESUMO - (Disjunção de Angiospermas Campos Rupestres - Restingas: uma reavaliação). Um padrão de distribuição disjunta entre as formações extrazonais conhecidas por campos rupestres na cadeia do Espinhaço e as restingas do litoral brasileiro vem sendo repetidamente proposto para algumas espécies de fanerógamas. Para averiguar a validade deste padrão, foram reunidos dados disponíveis em literatura e nos principais herbários. Verificou-se que algumas espécies aparecem adicionalmente nos campos rupestres das Serras de Goiás, campos de altitude da Serra do Mar, em formações rupestres geologicamente homólogas do Escudo das Guianas. Foram excluídas do padrão as espécies cuja ocorrência foi verificada também em vegetação zonal, tal como cerrado, caatinga e matas. O padrão campo rupestre-restinga se mostrou válido para 9 de 56 espécies investigadas (16\%). As razões apresentadas por distintos autores para explicar este padrão peculiar de disjunção são comparadas à luz de evidências geológicas e climatológicas.
\end{abstract}

Palavras-chave: disjunção, campo rupestre, restinga, fitogeografia, florística

\begin{abstract}
Angiosperm disjunction "Campos Rupestres - Restingas" - a re-evaluation). A disjunct distribution pattern between the extrazonal formations of the campos rupestres (rocky grasslands) in the Espinhaço mountain range and the restingas (coastal strand vegetation) in Brazil has been proposed repeatedly for several flowering-plant species. In order to validate this distribution pattern, available data from the literature and major herbaria were compiled and evaluated. Some of these species also occur in campos rupestres on mountain ranges in Goiás state, campos de altitude (high altitude grasslands) of the Serra do Mar, and on geologically homologous rocky formations of the Guyana shield. Species that were also recorded for distinct zonal formations like cerrado, caatinga and forests were excluded from the pattern. The campo rupestre-restinga disjunction proved valid for 9 of 56 investigated species (16\%). Explanations put forth by different authors for this unusual disjunction pattern are compared in the light of geological and climatological evidence.
\end{abstract}

Key words: disjunction, campo rupestre, restinga, phytogeography, floristics

\section{Introduction}

Campo rupestre is a peculiar vegetation type bound to a mosaic of rocky outcrops and shallow white sands occurring mostly above 1000 masl in southeastern and northeastern Brazil. While most vascular plants typical of this biome are not known to grow in other vegetation or soil types, a disjunct distribution with Atlantic coastal strand vegetation called restingas has been repeatedly reported for at least 56 species. We have tried to analyze the details of this peculiar campo rupestre - restinga distribution pattern, abbreviated hereafter as CR-R. It proved useful and necessary to compare these briefly with cerrado and caatinga, two zonal savannic vegetation types surrounding the campos rupestres, with potential stepping-stone outcrops such as the campos de altitude of the Serra da Bocaina and to some extent also with the tepuis of the Guyana shield. The main biomes treated herein can be briefly characterized as follows.

Cerrado, previously known as campos or campos cerrados, corresponds approximately to the Oreades (mountain nymph) floristic province in the classification of Martius. It is the largest contiguous Neotropical savanna, occurring also in patches surrounded by other vegetation types. From the cerrado biome, Sano \& Almeida (1998) report 6062 species (6389 taxa, including varieties) of flowering plants. Over 4000 of these species occur exclusively in the campos rupestres of the Espinhaço Range. Most of the cerrado species are adapted to periodical fires while several, known as pyrophytes, only complete their reproductive cycled when burned. In this biome, the zonal vegetation determined by the macroclimate, also known as cerrado, grows mainly on deep dystrophic latossols. The larger woody species of this habitat

\footnotetext{
1 Universidade Federal do Rio de Janeiro, Departamento de Botânica, Museu Nacional, Quinta da Boa Vista s.n., 20940-040 São Cristóvão, Rio de Janeiro, RJ, Brazil

2 Universidade Federal do Rio de Janeiro, Museu Nacional, Quinta da Boa Vista s.n., 20940-040 São Cristóvão, Rio de Janeiro, RJ, Brazil (leonorak@yahoo.com; cela_bio@yahoo.com.br)

3 Corresponding Author: ruyvalka@mn.ufrj.br
} 
frequently reach the deep water-table with their root systems, remaining green during the relatively dry winter months. The herb layer is seasonal, dry and hay-colored during the winter, green in the summer. The cerrado covers so large an area of Brazil that significant variation in soil and climate types can be found within its boundaries.

The caatinga is an arid zonal vegetation, mostly typical of northeastern Brazil, corresponding to Martius' Hamadryades floristic province. The vegetation physiognomy is variable and may sometimes technically be considered a savanna, but mostly the herb layer is rather discontinuous. Most plant species in the caatinga must quickly complete their life cycles during the ephemerous rainy season. With the notable exception of numerous Cactaceae the vegetation seems dry and dead for most of each year, vegetative and reproductive buds remaining dormant. The water table is usually out of reach to vegetation or nonexistent.

The campos rupestres are a species-rich, extrazonal vegetation complex bound to Precambrian quartzite outcrops which emerge as a mosaic surrounded mostly by cerrado and caatinga. Campo rupestre outcrops and associated white sands occur on table mountains and ranges elevated above surrounding vegetation types (for instance the ranges of Espinhaço, Mantiqueira, Chapada Diamantina, and several isolated ranges in the state of Goiás), and more rarely also as rocky pans entirely level with surrounding cerrado (part of the Itutinga and Espinhaço ranges in Minas Gerais, etc.) Most campos rupestres occur above $1000 \mathrm{~m}$ and the streams originating on these mountains have the potential to disperse diaspores toward the coast through rivers. Though they share some plant species with their savannic surroundings, the campos rupestres (Fig. 1C-E) should be considered a distinct floristic unit (Eiten 1978). Over 4000 vascular plant species have been recorded from the campos rupestres, but most of these have restricted distributions and many are narrow endemics. Individual localities along the Espinhaço Range can have up to $30 \%$ endemic species (Giulietti et al. 1987; Giulietti Pirani \& Harley 1997). Several distinct vegetation types comprise the campos rupestres, ranging from seasonally flooded meadows on white-sand with no shrub or tree layers to savannic tree-shrub formations with a contiguous herb layer and to communities on bare cliff faces. Between the $16^{\text {th }}$ century and the 1960 s, the natural campos rupestres of Minas Gerais have been reduced from 29,000 to 5,000 $\mathrm{km}^{2}$ and those of Bahia from 28,000 to $6,000 \mathrm{~km}^{2}$, representing a loss of $80.8 \%$ (Magnanini 1961).

The tepuis (Fig. 1B) are table mountains of Precambrian sandstone or quartzite, elevated above savannas and Amazonian rainforests in the Guyana Highlands of Venezuela with a few outliers in Brazil (Serra da Neblina, Monte Roraima, Serra do Araçá, de Tepequém, de Urutanim, de Uafaranda and de Surucucus). Due to prolonged isolation, the tepuis form a distinct floristic unit, but to a certain extent their vegetation physiognomy resembles that of the campos rupestres.

The restingas (Fig. 1G) are coastal strand ecosystems on Quaternary marine sand deposits, occurring on the Brazilian Atlantic coast from $4^{\circ} \mathrm{N}$ to $34^{\circ} \mathrm{S}$ (Araújo 2000). These coastal plains comprise a variety of plant communities determined by distinct topographies and by a combination of environmental variables of both oceanic and continental origin. Alternating sandy belts and lagoon systems are characteristic of the restingas (Suguio \& Tessler 1984; Flexor et al. 1984). With 131 families comprising over

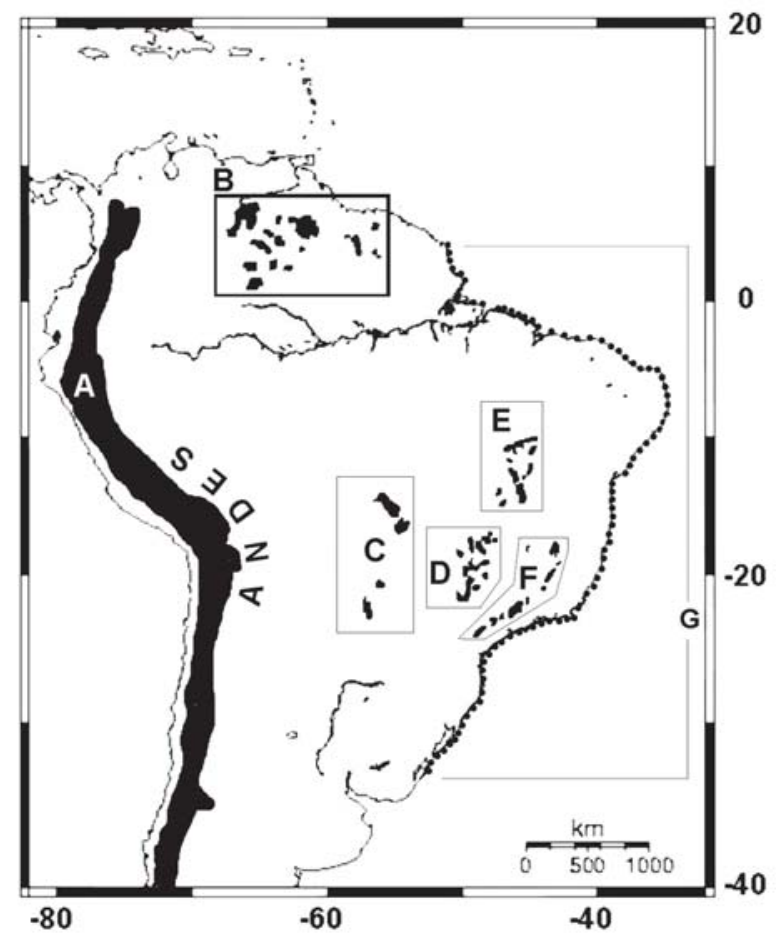

Figure 1. Phytogeographic units with outcrop vegetation: A. Andes. B. tepuis of the Guyana shield. C. Campos rupestres in mountain ranges of Goiás and Distrito Federal. D. Campos rupestres in south of the Espinhaço chain, Minas Gerais. E. Campos rupestres of the Chapada Diamantina (North of the Espinhaço chain, Bahia). F. Campos de altitude da Serra do Mar. G. Restingas (Atlantic coastal strand vegetation of Brazil). 
1400 species, the restinga flora is relatively rich (Restinga Net 2004). The floristic composition of the restingas changes greatly from north to south, passing from a tropical to a subtropical climate (Silva 1999). In the restingas of the state of Rio de Janeiro alone, 12 plant communities were distinguished by Araujo \& Henriques (1984). Since the $16^{\text {th }}$ century, over $90 \%$ of Brazilian restinga vegetation has been lost to urban development and other human activities (WWF 2002).

In the lower lands separating the Espinhaço Range and the coastal strands, some isolated mountain tops also have rock-dwelling vegetation. In southeastern Brazil these are exemplified by the campos de altitude ("high-altitude grassland vegetation"), in which many endemic species occur. These communities are usually on igneous bedrock such as gneiss or granite.

Analysis of such distinct environments calls for the comparison of some of their environmental factors.

Geology - The rocks which prevail in the mountain ranges of the Espinhaço Range are Precambrian quartzites (sandstones subject to metamorphism), exposed since the Tertiary (Harley 1995). The quartzite table mountains of the Guyana shield, or tepuis, are also Precambrian, formed between 1600 and 1000 Mya. (Steyermark et al. 1995). The frequent presence of ripple marks in both these rocks indicates their common genesis from lake-bed environments. Most campo de altitude vegetation occurs on gneiss or granite, with the exception of the highest ones on the Itatiaia plateau, formed by nepheline syenite. In both cases they arose in the Tertiary, simultaneously with the Andes (Ribeiro 2002). The sand deposits of the restingas are of Quaternary origin (1.8 - 0 Mya.), hence being geologically much younger than the aforementioned biotas. Due to their distinct physical and chemical properties, the latossols and other clayey soils which separate the campos rupestres from each other are covered by different vegetation such as cerrado, caatinga and various forests.

Restingas occur at sea level, cerrado and caatinga usually above $500 \mathrm{~m}$, campos rupestres and tepuis above $800 \mathrm{~m}$ and campos de altitude well above $1300 \mathrm{~m}$. In the tropics, most of these altitudinal differences alone are not expressive barriers to distribution. Mori \& Prance (1981) observe that, in addition to altitude, the Espinhaço Range is separated from the coastal strand by hundreds of $\mathrm{km}$ of humid forest.

Harley \& Simmons (1986) and Giulietti et al. (1997) claim that the campos rupestres and restingas share some climatic factors such as intense exposure to sunlight and frequent periods of high atmospheric humidity. Though detailed climatic studies at a plant community-based level are still lacking in all of these biotas, a comparison of available data from meteorological stations can illustrate how variable the climate can be among the mentioned biotas and even within the domain of a single vegetation type (Fig. 2). The climates vary so much that they can hardly contribute to explain the studied disjunct patterns of distribution. Variations of climatic factors are especially notorious along the coastal restingas: in the vicinity of Cabo Frio in northern Rio de Janeiro there is not a single month considered as rainy, while the beaches near Salvador in Bahia show just the opposite - a constantly rainy climate.

Frequent frosts and freezing temperatures in the campos de altitude may be a limiting factor to their potential function as stepping stones for the dispersal of campo rupestre species toward the restingas. Though these two biomes are separated by $250 \mathrm{~km}$ which do not support the survival of campo rupestre species, Harley (1995) considers the existence of "intermediate" environments in which some of these occur.

The distinct geologies, soil types and climates of campos rupestres and restingas force us to seek explanations for the CR-R distribution elsewhere.

Several authors have proposed the existence of a disjunct distribution pattern between the campos rupestres of the quartzite mountain ranges in Bahia, Minas Gerais and Goiás and the restingas along the Brazilian Atlantic coast. Giulietti \& Pirani (1988), and Harley (1995) described five main patterns for vascular plants found in the campos rupestres: (1) tropical American, (2) Espinhaço Range and Guyana shield, (3) Espinhaço Range and restingas, (4) Campos rupestres of the Espinhaço Range and of the mountain Ranges in Goiás, and (5) endemic to the Espinhaço chain. Based on the material of major herbaria and literature, we have addressed the third aforementioned distribution pattern and verified its pertinence for the species for which it has been proposed in literature.

Typical campo rupestre species would have originated in situ from savannic ancestors (Alves \& Kolbek 1994), later colonizing the restingas (Giulietti \& Pirani 1988; Harley \& Simmons 1986; Harley 1988) and sometimes occurring exclusively in these two biomes. These authors, along with Giulietti et al. (1997) suggest the CR-R distribution pattern for the species Anthurium affine Schott, Couma rigida Müll. Arg., 
Evolvulus jacobinus Moric., Phyllanthus angustissimus Müll. Arg., P. klotzschianus Müll. Arg., Mandevilla moricandiana (A. DC.) Woods., Marcetia taxifolia (A. St.-Hil.) DC., Mimosa lewisii Barneby, Lagenocarpus rigidus Nees, Vellozia dasypus Seub., Leiothrix rufula (A. St.-Hil.) Ruhland, Actinocephalus ramosus (Wikstr.) Sano, many species of Syngonanthus sect. Thysanocephalus and also for the genera Gaylussacia, Agarista, Allagoptera, Bonnetia, Eriope and Moldenhawera
Auyán Tepui (2100 m)

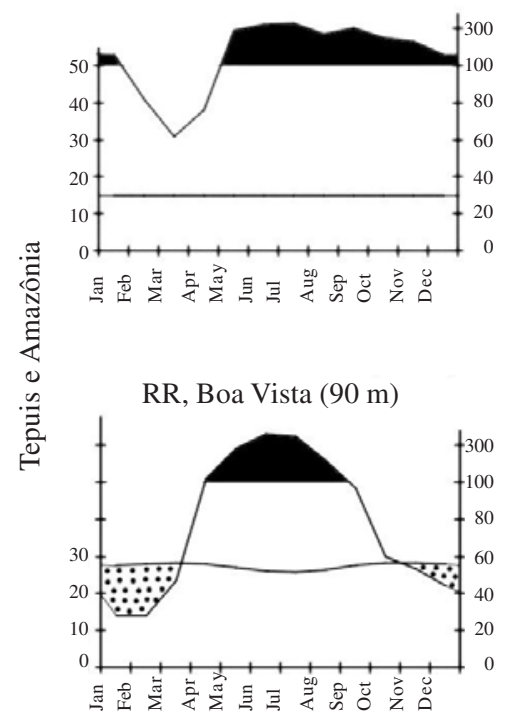

MG, Montes Claros (646 m)

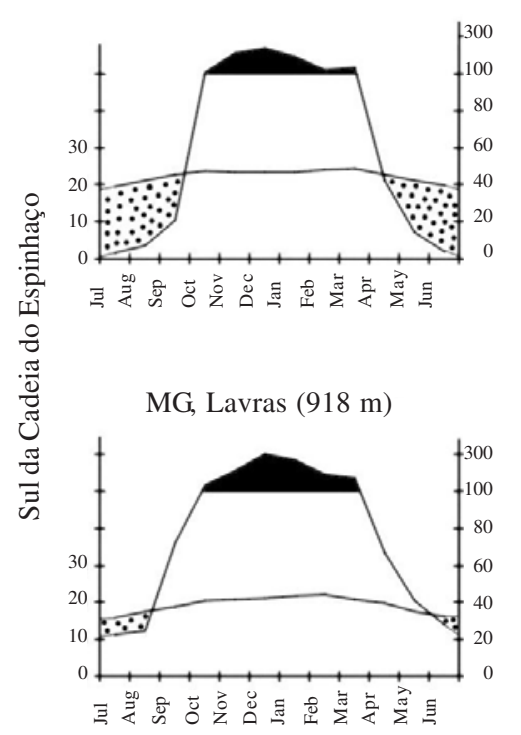

GO, Goiania (741 m)

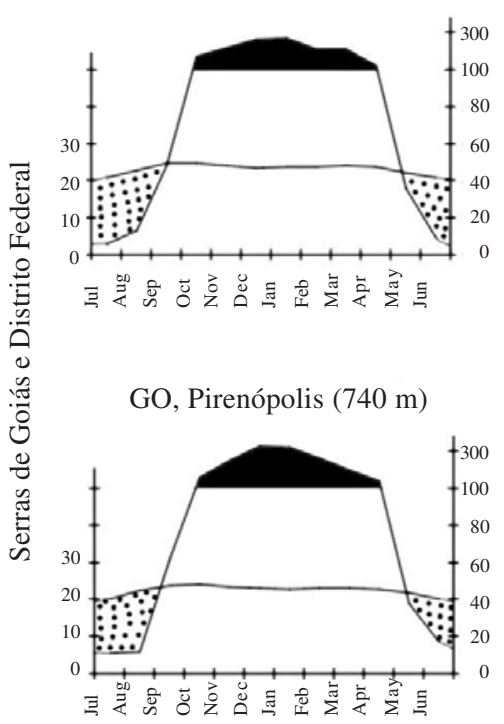

RJ, Itatiaia (2199 m)

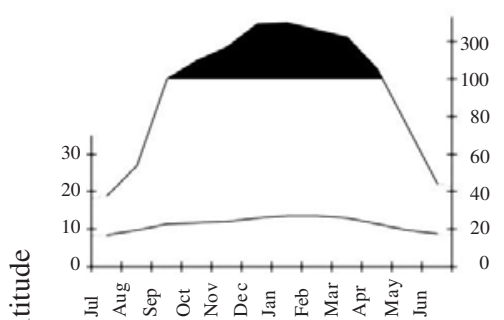

RJ, Bocaina (1480 m)

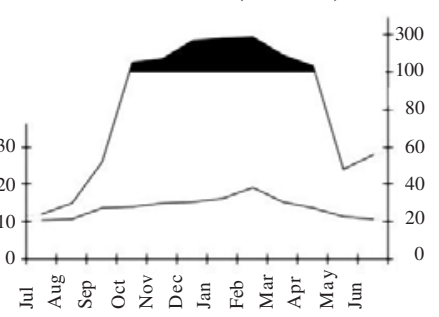

BA, Morro do Chapéu (2103 m)

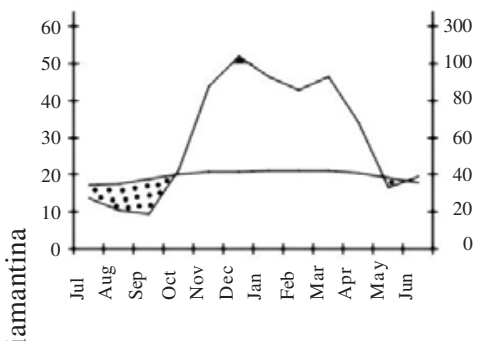

BA, Lençóis (439 m)

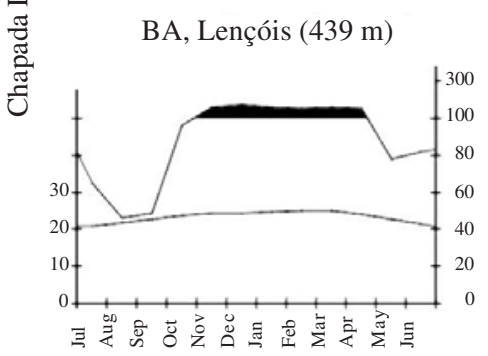

BA, Salvador $(51 \mathrm{~m})$

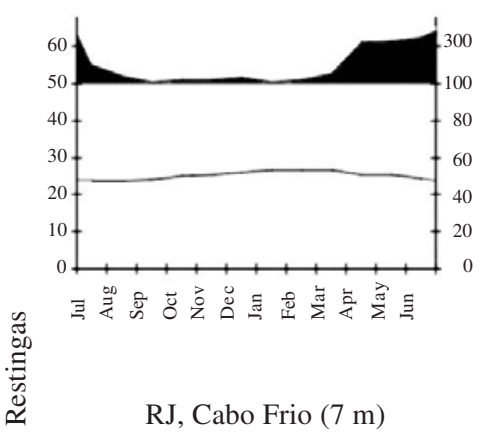

RJ, Cabo Frio (7 m)

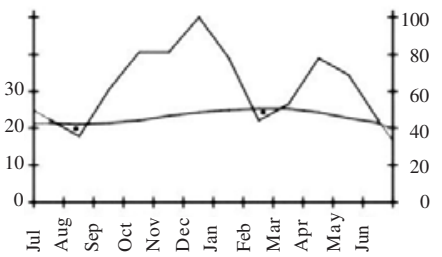

Figure 2. Walter climate diagrams of selected localities: Diagrams of tepuis, north of the equator, start with January, the remainder, in the southern hemisphere, with July. Climates alternating a dry and a wet season occur in campos rupestres of Goiás, Minas Gerais and in the tepui area of the Guyana shield (Boa Vista). Relatively arid climates occur in several biomes and altitudes, as exemplified by Morro do Chapéu (campo rupestre) and Cabo Frio (restinga). 
which do not have species common to both environments. Araujo (2000) considers Actinocephalus ramosus as occuring also in the "cerrado". Torres et al. (2003) suggest the CR-R pattern for Phyllanthus angustissimus and P. klotzschianus while Silva \& Giulietti (1997), in addition to these species also extend it to Drosera chrysolepis Taub. In a table, Araujo (2000) suggests the CR-R pattern for twelve species including Actinocephalus ramosus and Syngonanthus habrophyus Ruhland., but the text points to a broader distribution. One species widely believed to share the CR-R pattern is Melocactus violaceus Pfeiff. which occurs in the restingas (Costa \& Dias 2001) and disjunctly in the campos rupestres (Taylor 1991; Harley 1995; Taylor \& Zappi 2004). However, Taylor \& Zappi (2004) extend the distribution of $M$. violaceus to other habitats, with $M$. violaceus subsp. violaceus occurring also in cerrado and Atlantic rainforest, $M$. violaceus subsp. ritteri N.P. Taylor in caatinga and M. violaceus subsp. margaritaceus N.P. Taylor restricted to coastal strand.

The tepuis and the campos rupestres are disjunct centers of diversity for Xyridaceae and Eriocaulaceae, though few species are common to both. With over 100 species in the tepuis, the Rapateaceae, on the other hand, is represented in the campos rupestres by the single endemic Cephalostemon riedelianus Koern.

Giulietti et al. (1997) suggest that Marcetia taxifolia has an isolated occurrence in the tepuis and a diversity center in the Espinhaço chain. In the restingas of Rio de Janeiro State, M. taxifolia has pink corollas (Pangaio-Seda 2001), while those we have seen in the Espinhaço Range have white corollas, a difference studied in detail by Vale (1999). Martins (1989) considers the habit and corolla colors of $M$. taxifolia extremely variable, citing its occurrence also for the Andean Cordillera. A more detailed taxonomic study of this complex shall probably reveal several distinct sub-specific taxa.

Rizzini (1997) considers 23 genera as exclusive to the campo rupestre flora, citing Gaylussacia brasiliensis (Spreng.) Meissn., Moldenhauera cuprea Pohl and Pilocarpus spicatus A. St.-Hil. subsp. longeracemosus (Mart. ex Engl.) Kaastra as disjunct between the restingas and "certain central campos" but this last species also occurs in disturbed forests and other biomes. Another subspecies, P. spicatus subsp. spicatus, also occurs in forests.

Out of 32 species of Eriope, Harley (1988) considered 20 endemic to campos rupestres, five common to these and the cerrados, seven exclusive of cerrados, E. microstachya Mart. ex Benth. typical of gallery and humid montane forests and E. blanchetii (Benth.) Harley endemic to the restingas of Bahia. Harley (1988) further pointed out that the advancement of taxonomic classification can be a problem for mapping species distributions, exemplifying this by two subspecies of Hyptis parvifolia Mart. ex Benth., which he had initially split into four distinct species and later, transferring them to Eriope, recognized only two species: E. glandulosa (Harley) Harley and E. parvifolia Mart. ex Benth.

While obstacles to distribution from campo rupestre to restinga are notorious, they can also keep one campo rupestre isolated from another, as exemplified by the $300 \mathrm{~km}$ wide stretch of lowland separating the Chapada Diamantina in Bahia from the rest of the Espinhaço Range to the south, in Minas Gerais. Occasional isolated elevations with rocky outcrops scattered in the lowlands between the hinterland mountain ranges and the coastal strands are potential stepping stones for rock-dwelling species, and indeed Harley (pers. comm.) reports the presence of some typical campo rupestre species from the Serra de Itabaiana in Sergipe, the inselbergs of Milagres and also mountains such as the Serra do Orobó near Itaberaba, all well to the east of the Chapada Diamantina, Bahia. Despite these indications, we are considering only herbarium material as hard data for this paper, recognizing that a lot of further floristic investigation is necessary in order to have well established distribution maps.

Interpreting data on herbarium sheets does not always allow us to discern among campo rupestre plants and those from other formations. There are, however, clear cut examples: Pleurothallis (Orchidaceae) of the P. teres Lindl. complex or any species of Vellozia traditionally grow on rocky and sandy substrates. As most of the campos rupestres occur inserted within the cerrado and caatinga biomes, collectors sometimes do not distinguish the rockdwelling communities and annotate the zonal vegetation instead. This is a problem of scale, rather than a mistake.

Adoption of a broad scale may cause considerable trouble in distribution mapping. For Aechmea lingulata (L.) Baker, Marcetia taxifolia, Mitracarpus frigidus (Roem. \& Schult.) K. Schum. and Tillandsia stricta Soland., for instance, Pangaio-Seda (2001) proposed a "north peri-amazonic - Atlantic coast" distribution pattern, previously also adopted by Araujo (2000), referring to occurrence along the eastern and southern 
coast of Brazil and northern coast of South America (Venezuela and Guyana). Examination of herbarium material revealed that within the aforementioned broader areas, some of these species are truly restricted to the tepuis, not being as broadly distributed in those countries as the adopted pattern name would suggest. On the other hand, Tillandsia stricta has a much wider area of distribution than implied by these authors.

Analyzing the campo rupestre flora of the Serra do Ambrósio, Pirani et al. (1994) list 28 species as "broadly distributed in other open vegetation types such as campos, cerrados and restingas". They do not specifically indicate which of these species would have a CR-R distribution.

Hindsia (Rubiaceae) presents a peculiar distribution pattern, in campos rupestres and campos de altitude, restricted to four Brazilian massifs: Serra do Mar, Serra da Mantiqueira, Espinhaço Range e Chapada Diamantina, but not reaching the coast (Di Maio 1996). All these massifs share very ancient geologic surfaces.

\section{Material and methods}

Material in herbaria is the only scientific evidence for the occurrence of a certain species in a certain place and time. The analysis of distribution patterns in the present paper emphasizes the importance of such evidence, while taking into account some imprecision inherent to distinct collection efforts. Data on distribution are from the HB, HT, IT, K, NY, MBML, MO, R, RB, UB, US and VIES herbaria, from the NY and Restinga Net (2004) databases on the Internet and literature. Consulted floristic surveys of campo rupestre include the Serra do Cipó (Giulietti et al. 1987), Serra de São José (Alves 1992), Pico das Almas (Stannard 1995), and Mucugê (Harley \& Simmons 1986). Occurrence based on literature was considered only when herbarium material is specifically listed. Data from up to two specimens were compiled for each habitat. The campos rupestres south of the Ouro Branco range, exemplified by the São José, Lenheiro and Carrancas are here considered as part of the southern Espinhaço Range floristic unit, though they belong to distinct tectonic plate. The disjunct distribution patterns proposed by Araujo (2000), Mori et al. (1981), Giulietti \& Henshold (1990), Giulietti \& Pirani (1988), Giulietti et al. (1997), Harley (1988; 1995), Lima et al. (1997), Pirani et al. (1994), Pangaio-Seda (2001), Sano
(1998) and Sano et al. (2001) were verified. The species or subspecies for which the campo rupestre restinga, hereafter CR-R, pattern was proposed in literature were listed and sought out in herbaria. We also investigated a few campo rupestre species for which the CR-R pattern was not mentioned in literature. The aforementioned distribution pattern was confirmed only for those species not registered additionally from other vegetation types. Authorities are cited in the text only for species not listed in Table 1. Though discontinuous, the restingas were considered a single habitat along the Atlantic coast. When two materials from the same herbarium are cited, the herbarium acronym appears only after the second specimen. Countries are cited only in cases of extra-Brazilian material. States of Brazil are abbreviated. Observations from the herbarium tags were not transcribed. Although we insistently requested data on the distribution of Epistephium lucidum Cogn. according to instructions posted on the Internet, we obtained no reply from keepers of the NY and CAY databases. The cerrado concept is circumscribed according to Eiten (1978). Climates representing a broad range of variation were compared by means of Walter diagrams which were constructed from data in Steyermark et al. (1995) for Auyán Tepui in Venezuela, Segadas-Vianna \& Dau (1968) for the Itatiaia and Bocaina massifs, Companhia Nacional de Àlcalis (pers. comm.) for Cabo Frio and EMBRAPA (2004) for the remaining localities. The climatic data were stored in a Microsoft Excel file. In order to obtain uniform presentation of the climate diagrams, precipitation values exceeding $100 \mathrm{~mm}$ were divided by ten and added to the $100 \mathrm{~mm}$. For example, the value representing medium June rainfall of the Boa Vista station (RR), that is $356 \mathrm{~mm}$, was inserted as $100+25.6=126 \mathrm{~mm}$. This permitted automatic generation of line graphs easily transformed into .jpg image files and standard Walter climate diagrams. By convention the climate diagrams of tepuis, in the Northern Hemisphere start in January and those of the South Hemisphere in July. The geological ages of substrata were found in literature. The map (Fig. 1) was adapted from a mapmaking site on the Internet (Weinelt 2004).

\section{Results and discussion}

Not much is known about distribution patterns of Neotropical plant species and existing data are often biased by uneven collection efforts and lack of 
Table 1. Species per family, indicating occurrence in the treated biomes. $\mathrm{A}=$ Andes; $\mathrm{B}=$ tepuis of the Guyana shield; $\mathrm{C}=$ campos rupestres in mountain ranges of Goiás and Distrito Federal; D = campos rupestres in south of the Espinhaço chain, Minas Gerais, $\mathrm{E}=$ campos rupestres of the Chapada Diamantina (North of the Espinhaço chain, Bahia); F = Campos de altitude da Serra do Mar; $\mathrm{G}=$ restingas (Atlantic coastal strand vegetation of Brazil); $\mathrm{H}=$ Other ecosystems (broader distribution); $\mathrm{X}=$ occurrence proven by herbarium material.

\begin{tabular}{|c|c|c|c|c|c|c|c|c|c|}
\hline Family/Species & Sources for CR-R distribution & A & $\mathrm{B}$ & $\mathrm{C}$ & $\mathrm{D}$ & $\mathrm{E}$ & $\mathrm{F}$ & G & $\mathrm{H}$ \\
\hline \multicolumn{10}{|l|}{ ACANTHACEAE } \\
\hline Ruellia solitaria Vell. & Araujo (2000) & - & - & - & - & - & - & $\mathrm{X}$ & $\mathrm{X}$ \\
\hline \multicolumn{10}{|l|}{ APOCYNACEAE } \\
\hline Ditassa banksii Schult. & Araujo (2000) & - & - & - & - & - & - & $\mathrm{X}$ & $\mathrm{X}$ \\
\hline \multicolumn{10}{|l|}{ APOCYNACEAE } \\
\hline Macroditassa grandiflora (E. Fourn.) Malme & Araujo (2000) & - & - & - & - & $\mathrm{X}$ & - & $\mathrm{X}$ & $\mathrm{X}$ \\
\hline Couma rigida Müll. Arg. & $\begin{array}{l}\text { Harley \& Simmons (1986), } \\
\text { Giulietti et al. (1997) }\end{array}$ & - & $\mathrm{X}$ & - & $\mathrm{X}$ & - & - & $\mathrm{X}$ & - \\
\hline Mandevilla moricandiana (A.DC.) Woodson & $\begin{array}{l}\text { Mori \& Prance (1981), Harley \& Simmons } \\
\text { (1986), Harley (1995), Giulietti et al. (1997) }\end{array}$ & - & - & - & $\mathrm{X}$ & $\mathrm{X}$ & - & $X$ & $\mathrm{X}$ \\
\hline \multicolumn{10}{|l|}{ ARACEAE } \\
\hline Anthurium affine Schott & $\begin{array}{l}\text { Harley \& Simmons (1986), Harley (1995), } \\
\text { Giulietti et al. (1997) }\end{array}$ & - & - & - & $\mathrm{X}$ & $\mathrm{X}$ & - & $\mathrm{X}$ & $\mathrm{X}$ \\
\hline A. willdenowii Kunth & Araujo (2000) & - & - & - & $\mathrm{X}$ & $\mathrm{X}$ & - & - & $\mathrm{X}$ \\
\hline Philodendron leal-costae Mayo \& G.M. Barroso & Harley (1995) & - & - & - & - & - & - & - & $\mathrm{X}$ \\
\hline \multicolumn{10}{|c|}{ ASTERACEAE } \\
\hline $\begin{array}{l}\text { Bahianthus viscosus (Spreng.) RM.King \& } \\
\text { H.Rob. }\end{array}$ & Harley (1995) & - & - & - & - & - & - & - & - \\
\hline Vernonia crotonoides Sch. Bip. ex Baker & Esteves \& Esteves(2001) & - & - & - & - & $\mathrm{X}$ & - & $X$ & - \\
\hline \multicolumn{10}{|l|}{ BONNETIACEAE } \\
\hline Bonnetia stricta (Nees) Nees \& Mart. & $\begin{array}{l}\text { Mori \& Prance (1981), Harley \& Simmons } \\
\text { (1986), Harley (1995), Giulietti et al. (1997) }\end{array}$ & - & - & - & $\mathrm{X}$ & - & - & $\mathrm{X}$ & - \\
\hline \multicolumn{10}{|l|}{ CACTACEAE } \\
\hline Melocactus violaceus Pfeiff. & Taylor (1991), Harley (1995) & - & - & - & - & $\mathrm{X}$ & - & $\mathrm{X}$ & $\mathrm{X}$ \\
\hline \multicolumn{10}{|l|}{ CAMPANULACEAE } \\
\hline Lobelia camporum Pohl. & Pirani et al. (1994) & - & - & $\mathrm{X}$ & - & $\mathrm{X}$ & $\mathrm{X}$ & - & $\mathrm{X}$ \\
\hline \multicolumn{10}{|l|}{ CONVOLVULACEAE } \\
\hline Evolvulus jacobinus Moric. & $\begin{array}{l}\text { Harley \& Simmons (1986), Harley (1995), } \\
\text { Giulietti et al. (1997) }\end{array}$ & - & - & - & $\mathrm{X}$ & $\mathrm{X}$ & - & $\mathrm{X}$ & - \\
\hline \multicolumn{10}{|l|}{ CYPERACEAE } \\
\hline Lagenocarpus rigidus Nees & Harley (1995), Giulietti et al. (1997) & - & $\mathrm{X}$ & $\mathrm{X}$ & $\mathrm{X}$ & $\mathrm{X}$ & $\mathrm{X}$ & $\mathrm{X}$ & $\mathrm{X}$ \\
\hline Trilepis lhotskyana Nees ex Arn. & Harley (1995) & - & $\mathrm{X}$ & - & $\mathrm{X}$ & $\mathrm{X}$ & $\mathrm{X}$ & $\mathrm{X}$ & $\mathrm{X}$ \\
\hline \multicolumn{10}{|l|}{ DROSERACEAE } \\
\hline Drosera chrysolepis Taub. & Silva (1994), Harley (1995) & - & - & - & $\mathrm{X}$ & $\mathrm{X}$ & - & $\mathrm{X}$ & - \\
\hline \multicolumn{10}{|l|}{ ERICACEAE } \\
\hline $\begin{array}{l}\text { Gaylussacia brasiliensis (Spreng.) Meissn. } \\
\text { ERIOCAULACEAE }\end{array}$ & Rizzini (1997) & - & - & $\mathrm{X}$ & $\mathrm{X}$ & $\mathrm{X}$ & $\mathrm{X}$ & $\mathrm{X}$ & $X$ \\
\hline Actinocephalus ramosus (Wikstr.) Sano & $\begin{array}{l}\text { Giulietti et al.(1997), Pagano-Seda (2001), } \\
\text { Sano (1998) }\end{array}$ & - & - & - & $\mathrm{X}$ & $\mathrm{X}$ & $\mathrm{X}$ & $\mathrm{X}$ & - \\
\hline $\begin{array}{l}\text { Leiothrix flavescens (Bong.) Ruhland, } \\
\text { syn. }=\text { L. umbratilis Moldenke }\end{array}$ & Harley (1995), Giulietti \& Henshold (1990) & - & $\mathrm{X}$ & - & - & $\mathrm{X}$ & - & $\mathrm{X}$ & - \\
\hline L. hirsuta (Wikstr.) Ruhland & $\begin{array}{l}\text { Giulietti \& Pirani (1988), Harley (1995), } \\
\text { Araujo (2000) }\end{array}$ & - & - & - & - & - & - & $\mathrm{X}$ & - \\
\hline Leiothrix rufula (A.St.-Hil.) Ruhland & $\begin{array}{l}\text { Giulietti \& Pirani (1988), Harley (1995), } \\
\text { Giulietti et al. (1997), Araujo (2000) }\end{array}$ & - & - & - & $\mathrm{X}$ & - & - & $\mathrm{X}$ & - \\
\hline Syngonanthus habrophyus Ruhland & $\begin{array}{l}\text { Araujo (2000), Pagano-Seda (2001), Sano, } \\
\text { Parra \& Giulietti (2001), Giulietti \& Henshold } \\
\text { (1990) }\end{array}$ & - & - & - & - & $\mathrm{X}$ & - & $\mathrm{X}$ & - \\
\hline S. nitidus (Bong.) Ruhl. & Giulietti \& Henshold (1990) & - & - & - & - & - & - & - & - \\
\hline S. vernonioides (Kunth) Ruhland & Araujo (2000), Sano, Parra \& Giulietti (2001) & - & - & $\mathrm{X}$ & $\mathrm{X}$ & $\mathrm{X}$ & - & $\mathrm{X}$ & - \\
\hline \multicolumn{10}{|l|}{ FABACEAE } \\
\hline Mimosa lewisii Barneby & Giulietti et al. (1997) & - & - & - & - & $X$ & - & $\mathrm{X}$ & $\mathrm{X}$ \\
\hline
\end{tabular}


Table 1 (continuation)

\begin{tabular}{|c|c|c|c|c|c|c|c|c|c|}
\hline Family/Species & Sources for CR-R distribution & A & $\mathrm{B}$ & $\mathrm{C}$ & $\mathrm{D}$ & $\mathrm{E}$ & $\mathrm{F}$ & $\mathrm{G}$ & $\mathrm{H}$ \\
\hline Moldenhauera cuprea Pohl & Rizzini (1997) & - & - & - & - & - & - & $\mathrm{X}$ & - \\
\hline \multicolumn{10}{|l|}{ HUMIRIACEAE } \\
\hline Humiria balsamifera (Aubl.) St. Hil. & Mori \& Prance (1981) & - & $\mathrm{X}$ & - & - & $\mathrm{X}$ & - & $\mathrm{X}$ & $\mathrm{X}$ \\
\hline \multicolumn{10}{|l|}{ LAMIACEAE } \\
\hline Eriope blanchetii (Benth.) Harley & Harley (1988) & - & - & - & - & - & - & $\mathrm{X}$ & - \\
\hline Hyptis fruticosa Salzm. Ex Benth. & Harley (1995) & - & - & - & $\mathrm{X}$ & $\mathrm{X}$ & - & $\mathrm{X}$ & - \\
\hline Vitex polygama Cham. & & - & - & - & - & $\mathrm{X}$ & - & $\mathrm{X}$ & - \\
\hline \multicolumn{10}{|l|}{ LAURACEAE } \\
\hline Aniba firmula (Nees \& Mart.) Mez & Araujo (2000) & - & - & - & - & - & - & $\mathrm{X}$ & - \\
\hline \multicolumn{10}{|l|}{ MALVACEAE } \\
\hline Waltheria cinerascens St. Hil. & Mori \& Prance (1981) & - & - & - & - & - & - & $\mathrm{X}$ & $\mathrm{X}$ \\
\hline \multicolumn{10}{|l|}{ MELASTOMATACEAE } \\
\hline Comolia ovalifolia (DC.) Triana & See text & - & - & - & $\mathrm{X}$ & $\mathrm{X}$ & $\mathrm{X}$ & $\mathrm{X}$ & - \\
\hline \multicolumn{10}{|l|}{ MELASTOMATACEAE } \\
\hline Marcetia taxifolia (A. St.-Hil.) DC. & $\begin{array}{l}\text { Mori \& Prance (1981), Harley \& Simmons } \\
\text { (1986), Harley (1995), Giulietti et al. (1997) }\end{array}$ & $\mathrm{X}$ & $\mathrm{X}$ & - & $\mathrm{X}$ & $\mathrm{X}$ & - & $\mathrm{X}$ & $\mathrm{X}$ \\
\hline \multicolumn{10}{|l|}{ MOLLUGINACEAE } \\
\hline Mollugo verticillata $\mathrm{L}$. & Pirani et al. (1994) & - & - & - & - & $\mathrm{X}$ & - & - & - \\
\hline \multicolumn{10}{|l|}{ OLACACEAE } \\
\hline Heisteria perianthomega (Vell.) Sleumer & Araujo (2000) & - & - & - & - & - & - & $\mathrm{X}$ & - \\
\hline \multicolumn{10}{|l|}{ ORCHIDACEAE } \\
\hline Epistephium lucidum Cogn. & Harley (1995) & - & - & - & - & - & - & $\mathrm{X}$ & $\mathrm{X}$ \\
\hline \multicolumn{10}{|l|}{ PHYLLANTHACEAE } \\
\hline Phyllanthus angustissimus Mull. Arg. & $\begin{array}{l}\text { Giulietti \& Pirani (1988), Giulietti et al. } \\
\text { (1997), Torres et al. (2003) }\end{array}$ & - & - & - & $\mathrm{X}$ & $\mathrm{X}$ & - & $\mathrm{X}$ & $\mathrm{X}$ \\
\hline P. arenicula Casar. & Giulietti \& Pirani (1988), Oliveira (2001) & - & - & - & - & $\mathrm{X}$ & - & $\mathrm{X}$ & $\mathrm{X}$ \\
\hline P. klotzschianus Müll. Arg. & $\begin{array}{l}\text { Giulietti \& Pirani (1988), Giulietti et al. } \\
\text { (1997) }\end{array}$ & - & - & $\mathrm{X}$ & $\mathrm{X}$ & $\mathrm{X}$ & - & $\mathrm{X}$ & $\mathrm{X}$ \\
\hline \multicolumn{10}{|l|}{ POACEAE } \\
\hline Dichanthelium aequivaginatum (Swallen) & Harley (1995) & - & - & - & - & - & - & - & - \\
\hline Zuloaga (ex Panicum belmontae Renv.) & & & & & & & & & \\
\hline Eragrostis petrensis Renv. \& Longhi-Wagner & Harley (1995) & - & - & - & $X$ & - & - & - & - \\
\hline Panicum sacciolepoides Renv. \& Zuloaga & Harley (1995) & - & - & - & - & - & - & - & - \\
\hline P. trinii Kunth & Harley (1995), Araujo(2000) & - & - & - & $\mathrm{X}$ & $\mathrm{X}$ & - & $\mathrm{X}$ & - \\
\hline \multicolumn{10}{|l|}{ RUBIACEAE } \\
\hline Posoqueria acutifolia Mart. & Araujo (2000) & - & - & - & - & - & $\mathrm{X}$ & - & - \\
\hline Psychotria stachyoides Benth. & Araujo (2000) & - & - & - & - & - & $\mathrm{X}$ & - & $\mathrm{X}$ \\
\hline \multicolumn{10}{|l|}{ RUTACEAE } \\
\hline $\begin{array}{l}\text { Pilocarpus spicatus A. St.-Hil. } \\
\quad \text { subsp. longeracemosus (Mart. ex Engl.) Kaastra }\end{array}$ & Rizzini (1997) & - & - & - & - & $\mathrm{X}$ & - & $\mathrm{X}$ & $\mathrm{X}$ \\
\hline P. spicatus A. St.-Hil. subsp. spicatus & First reference here & - & - & - & $\mathrm{X}$ & - & - & $\mathrm{X}$ & $\mathrm{X}$ \\
\hline \multicolumn{10}{|l|}{ VELLOZIACEAE } \\
\hline Vellozia dasypus Seub. & $\begin{array}{l}\text { Harley \& Simmons (1986), Harley (1995), } \\
\text { Giulietti et al. (1997) }\end{array}$ & - & - & - & $\mathrm{X}$ & $\mathrm{X}$ & - & $\mathrm{X}$ & $\mathrm{X}$ \\
\hline \multicolumn{10}{|l|}{ XYRIDACEAE } \\
\hline Xyris augusto-coburgii Szyszy. & Giulietti \& Pirani (1988) & - & - & - & - & - & $\mathrm{X}$ & - & - \\
\hline$X$. bialata Malme & Wanderley (2001) & - & - & - & - & $\mathrm{X}$ & - & $\mathrm{X}$ & - \\
\hline$X$. ciliata Thunb. & Wanderley (2001) & - & - & - & $\mathrm{X}$ & - & - & - & - \\
\hline X. glandulacea Alb. Nilsson & Wanderley (2001) & - & - & - & $\mathrm{X}$ & - & - & - & - \\
\hline X. laxifolia Mart. & & - & $\mathrm{X}$ & $\mathrm{X}$ & $\mathrm{X}$ & $\mathrm{X}$ & $\mathrm{X}$ & $\mathrm{X}$ & $\mathrm{X}$ \\
\hline Xyris seubertii L.A. Nilsson & Harley (1995) & - & $\mathrm{X}$ & - & $\mathrm{X}$ & $\mathrm{X}$ & - & - & $\mathrm{X}$ \\
\hline
\end{tabular}

supporting herbarium evidence. The CR-R distribution pattern was confirmed for 9 of 56 studied species (16\%). Initially we intended to propose the CR-R pattern for Comolia ovalifolia; it was recently found in the Campos de Altitude of Serra do Brigadeiro (Caiafa \& Silva 2005). The obtained herbarium data indicates that the CR-R pattern seems valid for Vernonia crotonoides Sch. Bip. ex Baker, Bonnetia 
stricta (Nees) Nees \& Mart., Evolvulus jacobinus Moric., Drosera chrysolepis, Leiothrix rufula, Syngonanthus habrophyus, Syngonanthus vernonioides (Kunth) Ruhland, Panicum trinii Kunth and Xyris bialata Malme. The data also indicated the CR-R pattern for Vitex polygama Cham., but as Harley (pers. comm.) points out, this is a forest species and probably has a broader distribution.

Twenty one species (38\% of those for which the CR-R pattern was proposed in the literature) occur additionally in habitats with clayey soils such as cerrado and Atlantic rainforest. We were unable to locate sufficient material for confirmation of the CR-R pattern for (Spreng.) RM.King \& H.Rob., Moldenhauera cuprea, Leiothrix hirsuta (Wikstr.) Ruhl., Syngonanthus nitidus (Bong.) Ruhl., Eriope blanchetii (Benth.) Harley, Aniba firmula (Nees \& Mart.) Mez, Mollugo verticillata L., Heisteria perianthomega (Vell.) Sleumer, Eragrostis petrensis Renv. \& Longhi-Wagner, Dichanthelium aequivaginatum (Swallen) Zuloaga (Panicum belmontae Renv.), Panicum sacciolepoides Renv. \& Zuloaga, Xyris ciliata Thunb., and Xyris glandulacea Alb. Nilsson, of which we found material from either restinga or campo rupestre but not both.

In several cases the precision of proposed distribution patterns depends essentially on taxonomic revisions. According to the recent revision of Phyllanthus species with phylloclades by Santiago et al. (2006), Phyllanthus klotzschianus and $P$. angustissimus are documented by collections from Rio Grande do Sul and one further voucher of P. klotzschianus is from British Guyana, all of which do not specify vegetation type, leaving the CR-R pattern inconclusive for both species. Barneby (1991) already reports Mimosa lewisii from campo rupestre, restinga, and intermediate unspecified vegetation, hence excluding it from the CR-R pattern.

Rapini et al. (2001) cite Ditassa myrtilloides Frenzl. Ex E. Fourn. from campo rupestre of the Espinhaço range, and consider it similar to D. banksii Schult., common in coastal restingas but extending into Lagoa Santa, Minas Gerais (Cerrado). However, Konno (2005) believes that the occurrence of $D$. banksii in Minas Gerais may be a mistake caused by switched voucher labels.

The variability of altitudes, geologies and climates of the treated vegetation types suggests that soil drainage and nutrient poverty are probably the most important common factors which contribute to the
CR-R distribution pattern and occasionally to the additional occurrence of some species in the tepuis and campos de altitude. It is probably also the case of Marcetia taxifolia, which is disjunct in all these environments and additionally in the Andes. Though Safford \& Martinelli (2000) mention that the campos de altitude share taxa with campos rupestres, no species are directly referred. to this pattern. However, they do provide a curious case of vicarious species forming "monocotyledonous mats": Trilepis lhotskyana Nees ex Arn. on lower montane inselbergs and T. microstachya (Clark) H. Pfeiff. on summit level rocks at altitudes above $1700 \mathrm{~m}$. The latter species is also common in the campos rupestres above $1000 \mathrm{~m}$.

Distribution patterns are defined by different authors using distinct, sometimes misleadingly vague scales. Cases of narrow endemism, for instance, can be masked by indication of distribution restricted to political boundaries: a species endemic to a single campo rupestre range in Minas Gerais is also restricted to the state of Minas Gerais, to Brazil and to the Neotropics. Thorough investigation of all herbarium material and literature allied to the adoption of comparable mapping scales is the method by which most precision supporting a distribution pattern can be obtained. A single additional collection of the same species from a distinct locality can immediately redefine or invalidate any proposed distribution pattern, showing how dependent such patterns are on collection effort. Collection effort is also partly taxon-dependent: many Cactaceae and several other spiny taxa are severely under-represented in herbarium collections. The recognition of the distribution of specific biomes such as campos rupestres is also important in defining patterns of distribution: the CR-R pattern. For instance, several authors like Rapini et al. (2001) clearly do not recognize the existence of campos rupestres south of the Ouro Branco range, thus not recognizing the CR-R pattern for Couma rigida.

\section{Acknowledgments}

To colleagues Jorge Fontella Pereira, Tatiana Konno, Hilda Maria Longhi-Wagner, Laura Jane Santiago, Gustavo Martinelli, Haroldo Lima and Luiz Menini Neto for their contributions with data and suggestions; to Raymond Harley and Dorothy Araujo for their valuable suggestions and comments on the manuscript; to CAPES. 


\section{References}

Alves, R.J.V. 1992. The Flora \& Vegetation of the Serra de São José in Minas Gerais, Brazil. Tropicaleaf Nature Publishers, Praha.

Alves, R.J.V. \& Kolbek, J.1994. Plant species endemism in savana vegetation on table mountains (Campo Rupestre) in Brazil. Vegetatio 113: 125-139.

Araujo, D.S.D. 2000. Análise florística e fitogeografia das Restingas do Estado do Rio de Janeiro. Doctoral Thesis, Universidade Federal do Rio de Janeiro, Programa de Pós-Graduação em Ecologia, Rio de Janeiro.

Araujo, D.S.D. \& Henriques, R.B.P. 1984. Análise florística das restingas do Estado do Rio de Janeiro. Pp. 159193. In: Restingas: origem, estrutura, processos (L.D. Lacerda; D.S.D. Araujo; R. Cerqueira \& B. Turcq, orgs.).Universidade Federal Fluminense/ CEUFF, Niterói.

Barneby, R.C. 1991. Sensitivae Censitae. A description of the genus Mimosa L. (Mimosaceae) in the New World. Memoirs of the New York Botanical Garden 65: 1-835.

Caiafa, A.N. \& Silva, A.F. 2005. Composição Florística e Espectro Biológico de um Campo de Altitude no Parque Estadual da Serra do Brigadeiro, Minas Gerais - Brasil. Rodriguésia 56: 163-173.

Costa, A.F. \& Dias, I.C.A. (orgs.). Flora do Parque Nacional da Restinga de Jurubatiba e Arredores, Rio de Janeiro, Brasil: Listagem, Florística e Fitogeografia. Série Livros 8. Museu Nacional, Universidade Federal do Rio de Janeiro, Rio de Janeiro.

Di Maio, F.R. 1996. Revisão taxonômica do gênero Hindsia Bentham (Rubiaceae, Hedyotideae). Arquivos do Jardim Botânico do Rio de Janeiro 34: 51-92.

Eiten, G. 1978. Delimitation of the cerrado concept. Vegetatio 36: $169-178$.

EMBRAPA. 2004. Banco de Dados Climáticos do Brasil. http://www. bdclima. cnpm. embrapa.br /resultados / balanco.php? $\mathrm{UF}=\mathrm{rr} \& \mathrm{COD}=217$

Esteves R.L. \& Esteves V.G. 2001. Asteraceae. In: A.F. Costa \& I.C.A. Dias (orgs.). Flora do Parque Nacional da Restinga de Jurubatiba e arredores, Rio de Janeiro, Brasil: listagem, florística e fitogeografia. Série Livros, Museu Nacional, Universidade Federal do Rio de Janeiro, Rio de Janeiro.

Flexor, J.M.; Martin, L.; Suguio, K. \& Dominguez, J.M.L. 1984. Gênese dos cordões litorâneos da parte central da costa brasileira. Pp. 35-46. In: L.D. Lacerda; D.S.D. Araujo, R. Cerqueira \& B. Turcq (orgs.). Restingas: origem, estrutura, processos. Universidade Federal Fluminense, Rio de Janeiro.

Mori S.A.; Boom, B.M. \& Prance, G.T. 1981. Distribution patterns of eastern brazilian coastal forest tree species. Brittonia 33: 233-245.

Giulietti, A.M. \& Henshold, N. 1990. Padrões de distribuição geográfica dos gêneros de Eriocaulaceae. Acta Botanica Brasilica 4: 13-159.
Giulietti, A.M. \& Pirani, J.R. 1988. Patterns of geographic distribution of some plant species from the Espinhaço Range, Minas Gerais and Bahia, Brazil. Pp. 39-69. In: P.E. Vanzolini \& W.R. Heyer (eds.). Proceedings of a workshop on Neotropical Distribution Patterns. Rio de Janeiro, Academia Brasileira de Ciências.

Giulietti, A.M.; Pirani, J.R. \& Harley, R.M. 1997. Espinhaço Range Region, Eastern Brazil. Pp. 397-404. In: S.D. Davis et al. (eds.). Centres of plant diversity - A Guide and Strategy for their Conservation. World Wildlife Fund \& World Conservation Union.

Giulietti, A.M.; Menezes, N.L.; Pirani, J.R.; Meguro, M. \& Wanderley, M.G.L. 1987. Flora da Serra do Cipó, Minas Gerais: caracterização e lista das espécies. Boletim de Botânica da Universidade de São Paulo 9: 1-151.

Harley, R.M. 1988. Evolution and distribution of Eriope (Labiatae), and its relatives, in Brazil. Pp.71-120. In: P.E. Vanzolini \& W.R. Heyer (eds.). Proceedings of a workshop on Neotropical Distribution Patterns. Rio de Janeiro, Academia Brasileira de Ciências.

Harley, R.M. 1995. Introduction. Pp. 1-853. In: B.L. Stannard; Y. B. Harvey \& R.M. Harley (eds.). Flora of the Pico das Almas, Chapada Diamantina - Bahia, Brazil. Kew, Royal Botanic Gardens.

Harley, R.M. \& Simmons, N.A. (1986). Florula of Mucugê. Chapada Diamantina - Bahia, Brazil. Kew, Royal Botanic Gardens.

Konno, T.U.P. 2005. Ditassa R. Br. (Apocynaceae Asclepiadoideae) no Brasil. Doctoral Thesis, Universaidade de São Paulo.

Lima, M.P.M.; Guedes-Bruni, R.R.; Sylvestre, L.S.; Pessoa, S.V.A. \& Andreata, R.H.P. 1997. Padrões de distribuição geográfica das espécies vasculares da Reserva Ecológica de Macaé de Cima. Pp. 103-123. In: H.C. Lima \& R.R. Guedes-Bruni (eds.). Serra de Macaé de Cima: diversidade florística e conservação em mata atlântica. Rio de Janeiro, Instituto de Pesquisas Jardim Botânico do Rio de Janeiro.

Magnanini, A. 1961. Aspectos fitogeográficos do Brasil, Áreas e Características no Passado e no Presente. Revista Brasileira de Geografia 4: 93-102.

Martins, A. B. 1989. Revisão taxonômica do gênero Marcetia DC. (Melastomataceae). Tese de Doutorado. Universidade Estadual de Campinas, São Paulo.

Mori, S.A.; Boom, B.M. \& Prance, G.T. 1981. Distribution patterns of eastern brazilian coastal forest tree species. Brittonia 33: 233-245.

Mueller Argoviensis, 1863. Phyllanthus klotzschianus var. major. Linnaea 32: 1-53.

Oliveira, A.S. 2001. Euphorbiaceae. In: A.F. Costa \& I.C.A. Dias. Flora do Parque Nacional da Restinga de Jurubatiba e arredores, Rio de Janeiro, Brasil: listagem, florística e fitogeografia. Série Livros, Rio de Janeiro, Museu Nacional, Universidade Federal do Rio de Janeiro.

Pangaio-Seda, L.F. 2001. Padrões de distribuição geográfica das espécies da formação de Ericácea, Restinga de Itapebussus, Rio das Ostras, RJ. 73 pp., il. (dissertação, Museu Nacional, UFRJ). 
Pirani, J.R.; Giulietti, A.M.; Mello-Silva, R. \& Meguro, M. 1994. Checklist and patterns of geographic distribution of the vegetation of Serra do Ambrósio, Minas Gerais, Brazil. Revista Brasileira de Botânica 17: 133-147.

Rapini, A.; Mello-Silva, R. \& Kawasaki, M.L. 2001. Asclepiadoideae (Apocynaceae) na Cadeia do Espinhaço de Minas Gerais, Brasil. Boletim de Botânica da Universidade de. São Paulo 19: 55-169.

Restinga Net. 2004. Dados obtidos entre 19/05 e 25/05 de 2004. http:// www. restinga. net/default.asp

Ribeiro, K.T. 2002. Estrutura, Dinâmica e Biogeografia das Ilhas de Vegetação Rupícola do Planalto do Itatiaia, RJ. Tese (Doutorado em Ecologia), 121 fls., Instituto de Biologia, Universidade Federal do Rio de Janeiro.

Rizzini, C.T. 1997. Tratado de Fitogeografia do Brasil. 2 ed. Rio de Janeiro, Âmbito Cultural Edições, Ltd.

Safford, H.D. \& Martinelli, G. 2000. Southeast Brazil. Pp. 339-389. In: W. Bartlott \& S. Porembski (eds.). Inselbergs: Biotic diversity of isolated rock outcrops in Tropical and Temperate regions. Alemanha, Springer Verlag.

Sano, P.T. 1998. Flora da Serra do Cipó, Minas Gerais: Paepalanthus sect. Actinocephalus Koern. (Eriocaulaceae). Boletim de Botânica da Universidade de. São Paulo 17: 187-205.

Sano, P.T.; Parra, L.R. \& Giulietti, A.M. 2001. Eriocaluaceae. In: A.F. Costa \& I.C.A. Dias. Flora do Parque Nacional da Restinga de Jurubatiba e arredores, Rio de Janeiro, Brasil: listagem, florística e fitogeografia. Série Livros, Rio de Janeiro, Museu Nacional, Universidade Federal do Rio de Janeiro.

Sano, S.M. \& Almeida, S.P. 1998. Cerrado - ambiente e flora. Planaltina, Embrapa, Cpac.

Santiago, L.J.M.; Louro, R.P. \& Emmerich, M. 2006. Phyllanthus section choretropsis (Euphorbiaceae) in Brazil. Bot. Journ. Linn. Soc. 150: 131-164.

Segadas-Vianna, F. \& Dau, L. 1968. Ecology of the Itatiaia Range, Southeastern Brazil II. Climates and altitudinal climatic zonation. Arquivos do Museu Nacional 53: 31-53.
Silva, S.M. 1999. Diagnóstico das restingas do Brasil. In: Fundação Bio Rio (ed.). Workshop Avaliação e Ações Prioritárias Para a Conservação da Biodiversidade da Zona Costeira, Ilhéus, http// www.bdt.org.

Silva, T.R.S. \& Giulietti, A.M. 1997. Levantamento das Droseraceae do Brasil. Boletim de Botânica da Universidade de. São Paulo 16: 75-105.

Stannard, B.L. (ed.) 1995. Flora of the Pico das Almas, Chapada Diamantina - Bahia, Brazil. London, Kew, Royal Botanic Gardens.

Steyermark, J.A.; Berry, P.E. \& Holst, B.K. (eds.). 1995. Flora of the Venezuelan Guayana. v.1. St. Louis, Missouri Botanical Garden.

Suguio, K. \& Tessler, M.G. 1984. Planícies e cordões litorâneos quaternários do Brasil: origem e nomenclatura. Pp. 15-26. In: L.D. Lacerda; D.S.D. Araujo; R.Cerqueira \& B. Turcq (orgs.). Restingas: origem, estrutura, processos. Universidade Federal Fluminense, Rio de Janeiro.

Taylor, N.P. 1991. The genus Melocactus (Cactaceae) in Central and South America. Bradleya 9: 1-80.

Taylor, N \& Zappi, D. 2004. Cacti of Eastern Brazil. Champaign, Balogh International, Inc.

Torres, D.S.C.; Cordeiro, I. \& Giulietti, A.M. 2003. o gênero Phyllanthus (Euphorbiaceae) na Chapada Diamantina, Bahia, Brasil. Acta Botanica Brasilica 17: 265-278.

Vale, F.H.A. 1999. Comparação morfo-anatômica entre populações de Marcetia taxifolia (St.Hil.) DC. (Melastomataceae), localizadas na Serra do Cipó - MG e na restinga de Maricá - RJ. PhD Thesis. Universidade de São Paulo (n.v.).

Wanderley, M.G.L. 2001. Estudos taxonômicos no gênero Xyris L. (Xyridaceae) da Serra do Cipó, Minas Gerais, Brasil. Thesis, Instituto de Biociências, Universidade de São Paulo.

Weinelt, M. 2004. (http://www.aquarius.geomar.de/omc/ make_map.html )

World Wildlife Fund (WWF), 2002. http://www. worldwildlife. org/ wildworld /profiles/terrestrial/nt/ nt0102_full.html. 